ISSN 1676-3742

\title{
A urgência de um cristianismo unido ${ }^{1}$
}

\author{
Mario de França Miranda
}

\section{Resumo}

O texto trata da possibilidade de um cristianismo unido diante da atual sociedade, que desafia todas as Igrejas cristãs.

Reconhecendo que algumas divergências entre elas ainda necesssitam ser resolvidas, o autor procura demonstrar que certas diversidades não excluem a unidade, desde que fundamentada na pessoa de Jesus Cristo, numa eclesiologia de comunhão, e na missão comum de proclamar e realizar o Reino de Deus.

Palavras-chave: Cristianismo, Ecumenismo, Reino de Deus.

\section{Abstract}

This article is about the possibility of uniting all Christians in order to face the challenges of the current societies that might pose a threat to all christian churches.

It is common-sense that there are some divergent approaches amongst them, the author of this article, however, is coming forward to claim that

\footnotetext{
${ }^{1}$ Palestra proferida no Centro Universitário Bennet, por ocasião do Forum Bennet (2011).
} 
different opinions might be regarded as diversities within a united whole as long as these diversities have as a common foundation the person of Jesus Christ, an eclesiology of communion and a common mission to proclaim and to bring down God's Kingdom to earth.

\section{Key words: Christianity, Ecummenism, God's Kingdom.}

Confesso que não sou um perito em questões teológicas controvertidas entre as Igrejas cristãs. Deste modo também não me considero apto a entrar em temas que ocupam os especialistas desta modalidade teológica bem como do movimento ecumênico. Como então aceitei este convite? A resposta é simples: porque sou cristão dirigindo-me a um auditório de cristãos. Como alguém que professa sua fé em Jesus Cristo, que procura ser um seguidor do Mestre de Nazaré, sinto-me muito unido a todos vocês e mesmo feliz por ter a oportunidade de tratar um tema que é igualmente central para vocês e para mim. Confesso também que a presença de pastores, pastoras, leigos e leigas protestantes lá na PUC, que tive como alunos e alunas, e com os quais sempre tive um ótimo relacionamento, muito me ensinou a admirar neles a seriedade da fé, a coerência de vida e o interesse em aprofundar as verdades da revelação.

Quero deixar claro já de início o enfoque desta reflexão. Reconheço que o movimento ecumênico busca a união das Igrejas cristãs no respeito às características de cada uma delas. Reconheço, por outro lado, que esta meta do movimento ecumênico, mesmo apresentando uma fundamentação neotestamentária consistente, necessita de tempo, de dedicação, de humildade, de debate teológico, de respeito mútuo, de muita oração, para se tornar, de fato, uma realidade na história humana. Pois há pontos controversos importantes que, embora sejam atualmente vistos sem a atmosfera polêmica do passado e, portanto, possibilitando compreensões mais objetivas por parte das Igrejas envolvidas, constituem ainda diferenças de peso que não devem ser superficialmente escamoteadas. Reconheço, além disso, que alguma afirmação doutrinal por parte de uma Igreja pode ter um sentido positivo para as outras, ao convidá-las a uma revisão da própria compreensão. Assim, deste diálogo pode provir uma compreensão mais plena e rica da verdade revelada, mesmo sem ter ainda atingido a unidade pretendida.

Entretanto a atual situação do mundo cristão levou-me a preferir a expressão cristianismo unido em vez de insistir numa unidade eclesial inevitavelmente adiada para quando não sabemos. Entendo a expressão cristianismo 
unido como uma etapa prévia, incompleta, mas urgente devido ao enorme desafio à fé posto pela sociedade atual. Daí a urgência de um cristianismo unido para que este possa ter melhor presença e atuação no espaço público através da proclamação e da vivência do Reino de Deus. Pois julgo que o atual contexto sociocultural em que vivem hoje os cristãos difere muito daquele da época de cristandade que marcava o mundo ocidental. Naquele tempo as desavenças se situavam no interior de uma sociedade mais homogênea, estruturada principalmente pelas verdades e valores da fé cristã. As divergências doutrinais entre as Igrejas, mesmo se agravadas pelo fator cultural e político, se davam dentro de um contexto homogêneo e culturalmente cristão (cristandade).

Hoje o cristão se encontra inserido, quer queira, quer não, numa sociedade pluralista e secularizada que apresenta mentalidades e modos de vida bem diferentes do seu, fazendo-o se sentir como um estranho em seu próprio ambiente de vida. Com outras palavras, o cristianismo não é sem mais aceito, carecendo de força apelativa caso se apresente desunido e fragmentado. Está em jogo a própria credibilidade da fé cristã questionada pela atual sociedade. Ela só será plausível para nossos contemporâneos caso se apresente unida diante da sociedade, respeitadas as diferenças, as acentuações diversas, as práticas plurais encontradas nas Igrejas. Julgamos que esta unidade é possível se abandonarmos a atitude polêmica do passado por uma postura de mútuo respeito e colaboração, cientes de que a fé em Jesus Cristo que nos une é mais importante que as divergências que nos separam. Esta afirmação está subjacente a toda a nossa reflexão.

Outro ponto que nos guiou nesta reflexão foi a dimensão existencial da fé. Reconhecemos de antemão a importância da clareza doutrinal para a própria identidade do cristianismo. Mas constatamos que vivemos numa cultura marcada por uma inflação de discursos, que acaba por enfraquecê-los e relativizá-los mutuamente, numa cultura descrente de ideologias e teorias, mais sensível a ações humanizadoras, mais movida por realizações concretas em prol da justiça, da paz e da fraternidade, mais atingida por testemunhos de vida. Por isso mesmo julgamos dever ressaltar a vivência da fé por parte dos cristãos das diferentes Igrejas que, sem ignorar as divergências doutrinais, ganham hoje maior importância do que no passado. A história do cristianismo nos ensina que os grandes movimentos reformadores se originaram da busca de maior fidelidade ao Evangelho: assim o monaquismo na antiguidade, assim personagens como Gregório Magno, Francisco de Assis, Jan Huss, Lutero, John Wesley ${ }^{2}$. Nenhum deles pretendeu fundar nova Igreja, mas reformar

${ }^{2}$ M. HURLEY (ed.), John Wesley's Letter to a Roman Catholic, Belfast, 1968. 
espiritualmente a Igreja de sua época. Este fato confirma nossa convicção em enfatizar o peso do testemunho de vida dos cristãos para a atual sociedade.

Para tal vamos dividi-la em três partes. Primeiramente veremos os principais desafios à fé cristã em nossos dias que pedem uma maior união de todos os cristãos; em seguida examinaremos porque são inevitáveis as diferenças no interior do próprio cristianismo e como caminhamos para um cristianismo unido e plural no futuro; e numa terceira e última parte apontaremos as verdades cristãs fundamentais, geradoras de uma configuração futura do cristianismo que possa ser levado a sério e irradiar assim a mensagem cristã para a humanidade.

\section{As ameaças atuais à fé cristã}

A primeira delas pode ser caracterizada com o termo secularização ${ }^{3}$. A sociedade ocidental estava assentada no passado sobre verdades e valores cristãos, que lhe forneciam uma homogeneidade cultural e facilitavam sobremaneira a credibilidade e a difusão do cristianismo. As lutas religiosas no século XVI, a busca da paz e da convivência de todos na sociedade fizeram emergir outros fatores dominantes na organização social que prescindissem da religião e buscassem consenso apenas na força da razão. Deste modo se procurou construir a vida social fundamentada na racionalidade, na produtividade, na divisão de bens, com forte hegemonia do fator econômico. Esta tentativa de compreender o ser humano sem recorrer a realidades transcendentes gerou o que hoje conhecemos como o humanismo auto-suficiente, fechado, imanente. Embora enfraquecido pelas duas últimas guerras mundiais do século passado e pelas crescentes desigualdades sociais no planeta, ele ainda constitui o horizonte cultural no qual se move a parcela mais influente da atual sociedade. Felizmente a grande maioria do povo brasileiro demonstra ter ainda uma forte religiosidade de raiz cristã, mas não podemos evitar o efeito nocivo que nela exerce a cultura atual veiculada pela mídia.

Esta situação é agravada pelo atual pluralismo cultural que todos nós experimentamos. As ciências e as técnicas estão continuamente despejando no mercado cultural novos conhecimentos, novas interpretações da realidade, novos questionamentos, que se constituem como campos do saber dotados de racionalidade e linguagem própria, sem necessidade de referência alguma a qualquer fator que se situe fora de sua autocompreensão, como a fé em Deus

\footnotetext{
${ }^{3}$ Ver CH. TAYLOR, Uma era secular, São Leopoldo, Ed. Unisinos, 2010.
} 
ou em qualquer verdade religiosa. Deste modo a linguagem cristã se torna apenas mais uma neste mercado de interpretações plurais sobre o homem e o mundo. Inclusive a compreensão da mesma se torna mais difícil para nossos contemporâneos que vivem outras cosmovisões no seu dia a dia. Deste modo o mundo cristão pode ser enquadrado numa ótica de leitura meramente humana e visto apenas em sua dimensão histórica ou artística, como acontece com os monumentos erigidos pela fé cristã no passado e hoje reduzidos a meras atrações turísticas. Os símbolos cristãos podem se ver reduzidos a palavras e imagens sem substância própria, desnaturadas por utilizações espúrias e comerciais, sendo que a perda do seu mundo simbólico seria fatal para o cristianismo, pois é ele que garante sua continuidade histórica (doutrina, sacramentos, comunidade eclesial, práticas, etc.).

Outro sério desafio vem das demais religiões que hoje gozam de uma proximidade inédita na história da humanidade e que impelem o cristão a melhor conhecê-las e entendê-las em vista de uma convivência pacífica com seus membros. Deste modo o diálogo interreligioso passou a ser tema obrigatório na teologia cristã. Se confessamos um único Deus, criador de toda a realidade, que quer "que todos sejam salvos e cheguem ao conhecimento da verdade" (1 Tm 2,4), então não podemos negar a ação salvífica do Espírito de Deus em outras tradições religiosas, mas nem por isso devemos omitir ser Jesus Cristo o único mediador entre Deus e os homens (1 Tm 2,5), cuja salvação é universal e não limitada apenas aos cristãos. Ceder nesta questão equivale a destruir a identidade do cristianismo ${ }^{4}$. Infelizmente constatamos hoje falta de coerência e de espírito crítico em muitas afirmações proferidas em nome da tolerância e do diálogo. Entretanto não podemos igualar o cristianismo às outras religiões pela afirmação de que todas são boas, salvíficas e verdadeiras. Felizmente, neste ponto, há perfeita sintonia entre os melhores teólogos cristãos independente da respectiva Igreja.

Outro desafio provém da diversidade cultural dos povos. O fenômeno da globalização econômica arrastou consigo uma globalização cultural ao impingir às culturas nativas, nacionais ou regionais, visões da realidade e padrões de comportamento estandartizados, embutidos em seus produtos comerciais e tecnológicos. Este fato provocou uma forte reação por parte das

\footnotetext{
${ }^{4}$ W. PANNENBERG, Pluralismus als Herausforderung und Chance der Kirche, em: Id., Kirche und Ökumene. Beiträge zur Systematischen Theologie III, Göttingen, 2000, p. 31; K. RAHNER, Das Christentum und die nichtchristlichen Religionen, Schriften zur Theologie V, Einsiedeln, 1962, p. 136-158.
} 
culturas locais que tendem a enfatizar o que lhes é próprio para poderem sobreviver. A fé cristã enquanto recebida e vivida por homens e mulheres encontra-se sempre dentro de um contexto sociocultural concreto onde é entendida, expressa e vivida. Portanto a fé proclamada pelo missionário já é uma fé inculturada em seu país natal. Seus ouvintes, vivendo em outras culturas, querem também ser cristãos sem ter que renunciar a suas raízes culturais, a sua identidade social. Simplificando a questão: um africano não tem que se ocidentalizar para ser cristão, ele quer ser um cristão permanecendo africano. Devemos, portanto nos habituar a reconhecer no cristianismo ocidental, não o cristianismo universal, mas uma modalidade de cristianismo, embora com elementos e aquisições que não podem ser descartadas pelos demais povos. Ninguém desconhece o enorme problema constituído pela inculturação da fé semita no contexto sociocultural marcado pela racionalidade grego-romana. Pois o processo é difícil, longo e bastante arriscado como nos ensina a história dos grandes Concílios. Pois nem tudo nas culturas pode ser aceito pelo Evangelho. O imperativo da inculturação da fé constitui assim um desafio comum a todas as Igrejas cristãs.

A consciência moral da humanidade se desenvolve através da história em reação aos desafios dos diversos contextos existenciais e socioculturais que encontra, ou mesmo das conquistas provenientes das ciências modernas. Deste modo aflorou à consciência cristã que o mandamento do amor fraterno tinha em seu bojo uma exigência de mudança das estruturas sociais e das ideologias que as justificavam. Razão desta exigência estava no simples fato de que elas produziam desigualdades gritantes entre as classes sociais e sofrimentos humanos que poderiam ser evitados. Deste modo aparece a dimensão política da fé como um elemento que lhe é intrínseco por brotar do amor cristão por seu próximo. Entretanto haverá sempre o perigo de se instrumentalizar a fé pondo-a a serviço de um objetivo de cunho político, ainda que este seja bom para a sociedade. Seria fazer do cristianismo uma ideologia a favor de mudanças sociais que, realizadas ou frustradas, poderiam descartar posteriormente o cristianismo como uma ferramenta já inútil. Mas principalmente seria esquecer que o advento do Reino de Deus é obra de Deus e não nossa, embora devamos pedir e nos empenhar por sua realização.

O fenômeno do pentecostalismo em suas diversas manifestações e que tão fortemente se faz sentir em nosso país independentemente das respectivas confissões e comunidades cristãs, impressiona por sua rápida expansão e pelo entusiasmo que desperta em seus adeptos. As Igrejas históricas sentem 
o seu impacto, mas reconhecem ser difícil avaliar este fenômeno: reação a um cristianismo ocidental demasiado racionalizado? Ou iniciativa de Deus para despertar e vivenciar mais um cristianismo tradicional? Sem dúvida há muitos frutos positivos que confirmam a proveniência divina do fenômeno pentecostal. Mas também se deve cuidar para que o exercício da fé cristã não seja reduzido a experiências fortemente emotivas, centradas na própria pessoa, desconsiderando o compromisso cristão por uma sociedade mais justa já implícito na mensagem do Reino de Deus.

Ainda encontramos um novo desafio à fé cristã que decorre da cultura neoliberal dominante em nossa sociedade. Certos pregadores prometem cura súbita, felicidade imediata, soluções simples para os problemas vitais das classes mais carentes desde que paguem pelos serviços prestados. Essas agências religiosas de serviços por terem eficiente organização e saberem utilizar a mídia proliferam enriquecendo seus líderes. Os símbolos cristãos são utilizados então numa ótica funcionalista e lucrativa que os deturpa profundamente. Quando não mais apontam para as realidades salvíficas da fé cristã são "profanizados" como se exprimia Paul Tillich", tornam-se "ídolos". Se tivermos presente que a realidade salvífica do cristianismo, por ser Deus e de Deus, nos chega sempre através da linguagem dos símbolos, então o mau uso do nome de Jesus Cristo, da própria Bíblia, dos sacramentos, das preces ou mesmo do termo Igreja cristã, acaba por enfraquecer o próprio cristianismo, que vê seus símbolos desgastados e nossos contemporâneos descrentes dos mesmos.

\section{Um cristianismo uno e diverso}

Como já afirmamos anteriormente existem diferenças no interior do cristianismo que ainda separam as Igrejas e que devem ser objeto de futuros encontros ecumênicos. Temas como a sucessão apostólica, o ministério ordenado, a compreensão da eucaristia, do papado, da própria noção de comunidade eclesial não chegaram ainda a um consenso de fundo, como se deu com relação à primazia da Palavra de Deus no Concílio Vaticano II (Dei Verbum 10), ou com a noção de justificação (Declaração Conjunta sobre a doutrina da justificação da Igreja Católica Romana e da Federação Luterana Mundial). Por outro lado constatamos no interior do cristianismo uma diversidade tal

\footnotetext{
${ }^{5}$ P. TILLICH, Korrelationen, Stuttgart, 1975, p. 59-70.
} 
no tocante ao culto, à organização eclesial, às teologias, à pastoral, que nos perguntamos como é possível que em meio de toda esta diversidade todas as Igrejas apontem para o mesmo Deus, o mesmo salvador Jesus Cristo, o mesmo Espírito Santo que a todos santifica e fortalece? Será esta diversidade (não diferença) inevitável? Será ela apenas negativa e danosa, ou fator positivo e enriquecedor para o cristianismo? Não estariam por detrás de certas separações entre os cristãos apenas diferenças de cunho pessoal ou cultural que se apresentam como essenciais sem o serem de fato? ${ }^{6}$ Neste caso poderíamos ter um cristianismo que já apresenta certa unidade no respeito à diversidade plural de suas Igrejas. Aceitar esta afirmação nos leva a uma reflexão que a fundamente. É o que faremos a seguir nesta segunda parte.

A ação salvífica de Deus na história, seja no período de preparação à vinda de Jesus Cristo (Antigo Testamento), seja nos primórdios do cristianismo (Novo Testamento), só chega realmente a sua meta quando é acolhida na fé pelo ser humano. Assim, para os que não tinham fé, Jesus de Nazaré foi apenas um galileu exaltado e logo eliminado pelas autoridades religiosas de seu tempo. O gesto salvífico de Deus enviando seu Filho para nos salvar não foi por elas reconhecido. Portanto, só existe revelação salvífica de Deus quando a iniciativa divina é acolhida na fé pelo ser humano. Mas não existe o ser humano em geral, pois todos nós vivemos necessariamente no interior de um contexto vital, sociocultural, histórico, caracterizado por um horizonte de compreensão e uma linguagem bem determinada, dotada de idéias, experiências e práticas próprias.

Portanto, ao acolher na fé a ação salvífica de Deus, necessariamente toda esta realidade humana estará também presente. Pois o homem para aceitá-la deve entender a revelação salvífica de Deus, que se dará inevitavelmente dentro do seu respectivo horizonte cultural ${ }^{7}$. É a mesma ação divina, mas a diversidade plural daqueles que crêem faz com que haja diversidade nas expressões desta mesma fé 8 . Só assim explicamos a existência de quatro Evangelhos e a impossibilidade de reduzi-los a apenas um. Só assim explicamos a diversidade constatada na pneumatologia lucana, paulina ou joaneica. Só assim explicamos

\footnotetext{
${ }^{6}$ J. RATZINGER, A propos de la situation oecuménique, em: Id., Faire route avec Dieu, Paris, 2003, p. 239.

${ }^{7}$ Mesmo as dissensões presentes na história do cristianismo foram fortemente influenciadas pelo aspecto cultural, embora não exclusivamente. Ver Y. CONGAR, Diálogos de outono, São Paulo, Loyola, 1990, p. 70-74.

${ }^{8}$ K. RAHNER, Theologie im Neuen Testament, Schriften zur Theologie $V$, Einsiedeln, Benzinger, 1962, p. 33-53.
} 
a diversidade das comunidades eclesiais constituídas por cristãos judeus ou gentios tal como aparece na Igreja de Jerusalém e de Antioquia9.

A própria história do cristianismo nos atesta a pluralidade de expressões que apontam todas elas para o evento salvífico Jesus Cristo: expressões plurais de cunho doutrinal, litúrgico, pastoral, de organização comunitária. Além disso, a convivência de teologias diversas no interior do mesmo cristianismo confirma que os percursos biográficos e os modos de pensar dos que aderem a Jesus Cristo incidem fortemente em sua compreensão e expressão da fé. A já mencionada Declaração Conjunta sobre a Doutrina da Justificação demonstrou como é importante este fator no âmbito ecumênico. A síntese de Lutero tinha como princípio básico de sua teologia o "Deus que me salva". Já Tomás de Aquino partia da noção de "Deus criador e salvador". A teologia mais sapiencial de Tomás de Aquino e a teologia mais existencial de Lutero resultam de modos diversos de refletir a fé, que não podem ser reconciliados numa síntese posterior, mas que são legítimos no interior da mesma fé cristã ${ }^{10}$.

Também devemos considerar que a noção cristã de verdade se fundamenta na concepção bíblica, expressa no vocábulo emet: firmeza, consistência, fidelidade (entre pessoas). Algo que se comprova como digno de confiança é emet. Portanto esta concepção de verdade não pode prescindir do tempo, pois deve acontecer na história. Esta característica falta ao conceito grego de verdade que não acontece, mas simplesmente é. Daí não poder mudar. Entretanto a noção bíblica de verdade não se opõe à concepção grega, embora seja dela distinta, pois os feitos de Deus na história (o emet divino) são pressupostos como objetivamente verdadeiros no sentido grego. Assim as verdades de fé reivindicam validez universal e correspondência com a realidade, não se reduzindo a estados de ânimo ou situações existenciais ${ }^{11}$, embora abertas ao futuro.

Portanto a verdade cristã não pode ser contida num conceito, mas é acessível à fé enquanto esta última confia e se apóia no Deus que virá no futuro

\footnotetext{
${ }^{9}$ W. PANNENBERG, Pluralismus als Herausforderung und Chance der Kirche, em: Id., Kirche und Ökumene. Beiträge zur Systematischen Theologie III, Göttingen, 2000, p. 25s.

${ }^{10}$ Sobre este ponto ver: O. H. PESCH, Die Theologie der Rechtfertigung bei Martin Luther und Thomas von Aquin, Mainz, 1967; H. LEGRAND, La legitimité d'une pluralité des "formes de pensée" (Denkformen) en dogmatique catholique. Retour sur la thèse d'un précurseur: Otto Hermann Pesch, em: F. BOUSQUET (ed.), La responsabilité des théologiens. Mélanges offerts à Joseph Doré, Paris, 2002, p. 690-694.

${ }^{11}$ A. KREINER, Überlegungen zur theologischen Wahrheitproblematik und ihrer ökumenischen Relevanz, Catholica 41 (1987) p. 114-119.
} 
em plenitude ${ }^{12}$. Desse modo ela se opõe a qualquer tipo de dogmatismo, como infelizmente já se deu no passado. Hoje temos consciência do "já" e do "ainda não" que caracteriza as verdades da fé, pois a distância entre Deus e nós apenas nos permite expressá-lo de modo análogo e fragmentário. "Agora nós vemos num espelho, confusamente; mas, então, veremos face a face. Agora, conheço apenas em parte; mas, então, conhecerei completamente, como sou conhecido" (1 Cor 13,12). E como só podemos ter a verdade infinita de Deus na limitação das palavras humanas, estas últimas apontam corretamente para o mistério sem a pretensão de esgotar sua compreensão. Assim temos o todo no fragmento, a verdade da fé no instrumental lingüístico que dispomos. Nenhum conceito, estrutura mental ou horizonte cultural pode reivindicar a priori a mediação exclusiva da articulação da fé. Devemos afirmar o absoluto do mistério divino na condição humana que dá lugar, na questão da verdade da fé, a uma pluralidade.

No interior do cristianismo sempre tivemos não só escolas teológicas diversas, que acentuavam e articulavam diversamente os dados da fé, mas também liturgias, organizações eclesiais, práxis cristãs diversas, que davam lugar a configurações plurais da mesma fé. Todas elas são legítimas, iluminando determinados aspectos e deixando outros mais na sombra, testemunhando assim a impossibilidade de abranger toda a riqueza da fé numa só configuração. O que diversifica, neste caso, não rompe a unidade do cristianismo, nem o empobrece. Pelo contrário, manifesta mais plenamente essa mesma unidade presente na pluralidade de suas expressões.

A fé cristã é uma realidade viva, atual, abrangente. Como realidade viva deve ser vivida, sincrônica e diacronicamente, nos diversos ambientes culturais onde se encontra. Tal só é possível na medida em que é vivida e expressa nos variados contextos históricos onde se encontra, na medida em que é vivida numa pluralidade de vivências e de expressões. Mesmo as dissensões que ela apresenta confirmam que o aspecto cultural teve um grande peso, embora não exclusivamente. Portanto a diferença das confissões cristãs pode implicar uma necessidade histórica inevitável. Mas devemos observar que o clima polêmico fez com que as Igrejas radicalizassem o que tinham de próprio para garantir sua identidade. Esta afirmação atinge não só a doutrina, mas também a instituição como o culto, a organização, a ação caritativa, que marcam fortemente a religiosidade do fiel e dificultam mesmo qualquer mudança ${ }^{13}$.

\footnotetext{
${ }^{12}$ M. DE FRANÇA MIRANDA, Verdade cristã e pluralismo religioso, em: Id., A Igreja numa sociedade fragmentada, S. Paulo, 2006, p. 297-314.

${ }^{13}$ J.-P. WILLAIME, Les paradoxes contemporains de l'oecuménisme, em: Id., La precarité protestante. Sociologie du protestantisme contemporain, Genève, Labor et Fides, 1992, 174s.
} 
Devemos também considerar que nem todas as verdades cristãs têm a mesma importância. Podemos mesmo falar de uma hierarquia de verdades ${ }^{14}$ conforme a proximidade e o nexo de cada uma delas com o núcleo da fé cristã. Este está constituído pelo mistério da vida, morte e ressurreição de Jesus Cristo, no qual temos a revelação do Deus Trino e o acesso à nossa salvação. É o que vem enfatizado na recente Declaração Conjunta sobre a Doutrina da Justificação (n.18). Já Tomás de Aquino, ao afirmar ser a doutrina revelada uma doutrina salvífica, distingue as verdades de fé que concernem o fim, a saber, a própria salvação, e as aquelas que dizem respeito aos meios salvíficos. As diferenças doutrinárias teriam mais relação com estas últimas ${ }^{15}$. Neste sentido podemos afirmar que a pessoa de Jesus Cristo constitui o critério central para uma hierarquização das verdades de fé.

Daqui se segue uma importante consequência para sabermos avaliar as diferenças de cunho doutrinal já que todas elas não gozam de igual importância, dependendo de sua relação com este núcleo salvífico. De fato, elas constituem uma totalidade orgânica em torno do mistério de Jesus Cristo ${ }^{16}$. Contudo a hierarquia das verdades de fé não constitui um critério que determine quantitativamente o que é normativo para a fé cristã, mas abre espaço para acentuações diferenciadas e configurações plurais do núcleo da fé. E também para as "identidades confessionais", que representam a fé vivida num contexto eclesial determinado, constituído não só pela doutrina, mas também pelo testemunho, pelo culto, pela comunidade, pelo serviço. Não poderiam algumas diferenças doutrinárias das confissões ser consideradas como compreensões diferenciadas do mistério central, conforme o contexto existencial e sociocultural de quem o acolhe e, portanto, legítimas? Hipótese séria, mas que não pretende desacreditar as diferenças reais, mas incentivar seu estudo para desfazer preconceitos e favorecer a união. Desse modo não se perderia toda a riqueza de leituras e vivências aí presentes, fortalecendo a tese de uma unidade na pluralidade, expressa por J. Ratzinger como "permaneçam as Igrejas e, contudo se tornem uma Igreja"17, ou da tese do consenso diferenciado, defendida hoje no diálogo ecumênico ${ }^{18}$.

\footnotetext{
${ }^{14} \mathrm{~W}$. HENN, The Hierarchy of Truths and Christian Unity, Ephemerides Theologicae Lovanienses (1990) p. 112.

${ }^{15}$ W. THÖNISSEN, Hierarchia Veritatum. Eine systematische Erläuterung, Catholica 54 (2000) p. 183.

${ }^{16}$ W. PANNENBERG, Das protestantische Prinzip im ökumenischen Dialog, em: Id. Kirche und Ökumene, Göttingen, p.190.

${ }^{17}$ Citado por W. KASPER, Katholische Kirche, Freiburg, Herder, 2011, p. 436.

${ }^{18}$ M. STRIET, Denkformgenese und -analyse in der Überlieferungsgeschichte des Glaubens, em: H. WAGNER (ed.), Einheit _ aber wie? Zur Tragfähigkeit der ökumenischen Formel vom
} 


\section{Eixos centrais de um cristianismo unido}

Trata-se de oferecer verdades cristãs que hoje devem ser realçadas em todas as comunidades cristãs e que fortalecem a unidade do cristianismo diante da atual sociedade. Embora a escolha destes eixos seja pessoal e, portanto, subjetiva, procurarei justificar a seguir esta minha opção. Confesso que ela brotou em boa parte dos desafios pastorais enfrentados pelas Igrejas que, bem examinados, se assemelham em todas elas.

\section{A pessoa de Jesus Cristo}

Pode-se notar nas Igrejas cristãs uma preocupação com sua manutenção, seu crescimento, sua identidade, que acaba por ocupar seus responsáveis com questões de cunho administrativo e pastoral. É um fenômeno natural desde que não se transforme num eclesiocentrismo que veja as demais comunidades cristãs como rivais ou concorrentes ou que não dê a devida importância à proclamação da pessoa e da mensagem de Jesus Cristo. Pois aqui temos o núcleo da fé cristã, que é primordial e anterior a todas as demais expressões, práticas ou organizações que caracterizam uma Igreja cristã.

Numa época em que a fé cristã não é mais respaldada pela sociedade como se dava no passado, em que crenças religiosas são oferecidas generosamente como num mercado, em que as instituições eclesiais lutam para acompanhar as transformações profundas e sucessivas da sociedade, em que os valores tradicionais, mesmo religiosos, não são mais automaticamente aceitos, torna-se a transmissão da fé às novas gerações um problema central para as Igrejas cristãs. É o momento de proclamarmos a pessoa de Jesus, sua vida, sua história, sua mensagem, tal como nos apresentam os Evangelhos, pois a força atrativa que dela emana não deixará de impactar as gerações mais jovens, descrentes da cultura consumista e descartável, vazia de referências substantivas que os orientem na aventura da vida ou que indiquem onde investir a própria liberdade na construção de sua autobiografia. A mensagem cristã potencializa o que há de melhor no coração humano, se realmente apresentada como se deve.

differenzierten Konsens, Freiburg, Herder, 2000, p. 63s; W. PANNENBERG, Pluralismus als Herausforderung, ob. cit., p. 29; H. MEYER, Diversidade reconciliada - o projeto ecumênico, São Leopoldo, Sinodal, 2003. 
As Igrejas acumularam ao longo dos anos muitas tradições e práticas contingentes, históricas, humanas, que caracterizam seu perfil, mas que podem também encobrir o núcleo da fé cristã, como poeira que se acumula numa obra de arte e impede que seja admirada pelo seu valor. $\mathrm{O}$ cristianismo não toma sem mais partido pela herança institucional religiosa, pois assim como rejeita os ídolos, acolhe a opção rebelde que brota da consciência ${ }^{19}$. Enfatizo este ponto: devemos apresentar aos jovens o caminho de Jesus como uma possibilidade de realização da liberdade. De fato, a adesão a Jesus Cristo na fé é uma opção livre, que parte de dentro da pessoa ao aceitar a graça da fé. Esta opção, por ser livre, tem seu risco como tão bem experimentaram os primeiros cristãos. Um risco que se fundamenta não numa argumentação, mas numa pessoa, como tão bem exprime Paulo: "Sei em quem depositei minha fé" (1Tm 1,12). Esta opção livre deve ser respeitada e fomentada pela instituição eclesial, às vezes mais preocupada em enquadrar o fiel em suas práticas.

Juntamente com a ênfase posta na pessoa de Jesus está a importância de recuperarmos a verdadeira imagem de Deus revelada na vida e nas palavras do Mestre de Nazaré. Pois imagens deformadas de Deus e veiculadas pelos próprios cristãos podem constituir um sério obstáculo à credibilidade do cristianismo e à atividade missionária das Igrejas. Um Deus juiz e controlador, um Deus distante e ausente, um Deus que incita à violência, um Deus tapaburaco para momentos difíceis, um Deus ciumento do progresso humano, um Deus concebido à nossa imagem e semelhança, um Deus todo-poderoso, são representações de Deus herdadas do passado e ainda vigentes em nossos dias. Já o Deus de Jesus, já que Jesus é a imagem perfeita do Pai (Jo 14,9), se revela nas ações e nas palavras do Mestre de Nazaré, onde emerge seu amor incondicional por todo ser humano, sua compaixão pelos mais pobres e marginalizados, sua misericórdia diante do sofrimento humano, seu perdão sem reservas diante do pecado, sua humildade diante da liberdade humana, enfim sua preocupação com a felicidade do homem ao procurar diminuir seus sofrimentos físicos e morais. É preciso dar um conteúdo cristão à palavra "Deus", temido por muitos cristãos e invocado diversamente por não cristãos. Nosso Deus é o Deus de Jesus Cristo nosso único acesso verdadeiro ao Mistério Infinito que nos envolve ${ }^{20}$.

\footnotetext{
${ }_{19}$ J. RATZINGER, Der christliche Glaube und die Weltreligionen, em: H. VORGRIMLER (Hrsg.), Gott in Welt. Festgabe für Karl Rahner II, Freiburg, 1964, p. 290.

${ }^{20}$ J. M. CASTILLO, Deus e nossa felicidade, S. Paulo, Loyola, p. 23-42.
} 


\section{A comunhão das Igrejas}

A fé na pessoa de Jesus Cristo e no Deus por ele revelado constitui os cristãos e as cristãs como um grupo social determinado na grande sociedade humana. Este grupo visibiliza e torna realidade para o mundo a ação salvífica de Deus na história pela profissão de fé, pela celebração dos sacramentos e pela vivência cristã de seus membros. Este grupo se compreendeu, desde o seu início, como o novo Povo de Deus, como uma comunidade de fiéis destinada a anunciar e realizar a mensagem evangélica do Reino de Deus. Sabemos pela história do cristianismo que outras comunidades foram se originando fora da Palestina, organizando-se diversamente conforme os contextos socioculturais respectivos. Mas todas invocando o mesmo Deus, confessando o mesmo Senhor Jesus e vivendo sob a ação do mesmo Espírito.

O cristianismo era então uma comunhão de Igrejas porque todas participavam dos mesmos bens salvíficos. Esta comunhão era, sobretudo, com o Pai e o Filho no Espírito (1Jo 4,12s) e se fundamentava, em última instância, no próprio ser de Deus, que existe como comunhão. Esta eclesiologia de comunhão estava muito difusa no primeiro milênio do cristianismo. Ela não era impedida por configurações diversas do crer em Jesus Cristo, do viver os valores evangélicos, do organizar a comunidade cristã, do celebrar o culto e os sacramentos, do determinar a ação missionária. Portanto, a diversidade sempre existiu no cristianismo. Algumas resultaram em rupturas sérias na unidade cristã, como a separação dos cristãos do Oriente e a Reforma protestante. Mesmo sem desconhecer pontos controversos que exigem tempo, estudo, abertura ao diálogo para serem devidamente captados e valorizados, podemos afirmar que existe uma profunda unidade de todas as comunidades cristãs, fundamentada na mesma fé e na mesma missão que lhes fornece sua própria identidade.

As diferenças, que não devem ser escamoteadas, podem ser melhor compreendidas e toleradas se tivermos em consideração que ter a verdade da fé não significa que a tenhamos captado em toda a sua riqueza e profundidade como já nos alerta o apóstolo Paulo: “Agora nós vemos num espelho; mas, então veremos face a face" (1Cor 13,12) $)^{21}$. Além disso, temos que reconhecer que as diversas Igrejas cristãs podem representar configurações diversas da mesma fé, dotadas de valor único já que completa e enriquece o cristianismo,

${ }^{21}$ W. PANNENBERG, 'Glaube und Kirchenverfassung' in einer säkularisierten Welt, em: Id., Kirche und Ökumene, p. 243. 
e deste modo jamais deveriam desaparecer ${ }^{22}$. Fundamental é aqui constatar que o que une as Igrejas cristãs é muito maior do que as separa. Pois todas elas aí estão, e não têm outro sentido senão manifestar e tornar realidade o Reino de Deus. Não é suficiente, como aconteceu em grande parte no passado, a discussão em torno dos elementos institucionais, presentes ou não, nesta ou naquela Igreja, mesmo que tal debate seja necessário e possa redundar em proveito de todas elas. Pois o institucional recebe sua legitimidade e sentido enquanto está a serviço do Reino de Deus.

Com outras palavras, o testemunho dos fiéis como comunidade eclesial, vivendo com coerência sua vocação cristã, deve ser mais valorizado no interior do cristianismo. A proclamação da Palavra, a administração dos sacramentos, os ministérios de governo, devem ser fecundos, ou seja, fazer crescer o Reino de Deus. Esse ponto é de grande importância para o tema da comunhão das Igrejas, pois a diversidade de configurações institucionais pode ter se dado em vista de tornar o institucional (meio) realmente salvífico ${ }^{23}$. Numa sociedade secularizada que já apresenta dificuldade em entender a linguagem cristã e que se encontra à mercê de uma inflação de discursos de todo tipo, o testemunho de vida ganha enorme realce. E em todas as Igrejas cristãs encontramos esta coerência de vida, esta vivência contra-cultural, esta manifestação da presença e da graça de Deus que assinala para nossos contemporâneos que o Reino de Deus realmente acontece no interior da história.

Este fato deveria ser mais enfatizado nas Igrejas, Pois o institucional, o sacramental, o jurídico, o organizativo, o doutrinal, o teológico está (ou deveria estar) necessariamente enraizado na experiência salvífica da graça de Deus que transformou o cristão e o levou a pôr-se a serviço da grande missão: "Ide, pois, fazer discípulos entre todas as nações" (Mt 28,19). Não foi, afinal, a causa do Reino de Deus, que levou Lutero a tentar uma reforma da sua própria Igreja, já que não pretendia fundar outra, mas não teve a compreensão da parte de seus responsáveis ${ }^{24}$ Sabemos que a vivência da salvação, a dimensão existencial da fé, sempre teve enorme influência em sua vida e em sua teologia. Sua crítica às instituições e práticas decadentes de sua época ao enfatizar a

${ }^{22}$ H. WAGNER, Konfessionen und Ökumene eine Widerspruch?, em: F. CHICA-S. PANIZZOLO-H. WAGNER (Ed.), Ecclesia Tertii Millenni Advenientis. Omagio al P. Angel Antón, Casale Monferrato, 1997, p. 335s.

${ }^{23}$ O. H. PESCH, Hermeneutik des Ämterwandels?, em: P. WALTER-K. KRÄMER-G. AUGUSTIN (Hrsg.), Kirche in ökumenischer Perspektive, Freiburg, Herder, 2002, p. 417-438.

${ }^{24}$ J. DELUMEAU, Naissance et affirmation de la réforme, Paris, 1965, p.66; W. PANNENBERG, Reformation und Einheit der Kirche, em: Id., Kirche und Ökumene, p. 174. 
imediatidade do cristão com Deus, de onde hauria sua liberdade, não excluía a mediação humana ou institucional, cuja finalidade era exatamente possibilitar tal relacionamento direto com Deus ${ }^{25}$.

Volto a insistir. Numa sociedade pluralista entregue a toda sorte de compreensões da realidade, também de cunho religioso por parte das grandes religiões tornadas próximas, é fundamental que o cristianismo se encontre unido, no respeito à diversidade das confissões, se quiser gozar de credibilidade e poder transformar a humanidade na grande família de Deus, meta escatológica que só se realizará perfeitamente na outra vida, mas que deve ser buscada por todo cristão no interior da história. Se quisermos ter vez e voz na vida pública, temos que nos apresentar unidos, já que nossa missão é comum, mesmo reconhecendo devermos continuar nos esforçando para alcançar a verdade nos pontos controversos ${ }^{26}$. Para alcançar este objetivo temos que mudar nossa atitude com relação às demais Igrejas cristãs. Se no passado caímos num eclesiocentrismo voltados principalmente para nossa própria comunidade, hoje se faz necessário respeitar, conhecer e colaborar uns com outros na missão comum diante da sociedade secularizada e pluralista.

\section{A missão comum}

Toda a pessoa e a vida de Jesus só se entendem à luz do Reino de Deus. Não podemos cair num "reinocentrismo" sem Jesus, nem num "cristocentrismo" sem o Reino. No primeiro caso transformaríamos o cristianismo numa ideologia; no segundo, estaríamos tornando ininteligível a atividade salvífica de Jesus. Portanto a missão de proclamar o Evangelho, de anunciar a boa-nova da salvação ao mundo, implica necessariamente uma referência ao Reino de Deus já presente nas palavras e nas ações do Mestre de Nazaré, mas que terá sua plenitude na outra vida. Nesta noção entra primeiramente a soberania de Deus manifestada em seu amor incondicionado pelos seres humanos. $\mathrm{Na}$ medida em que esta iniciativa divina é acolhida, então a pessoa se transforma, se liberta de seu egoísmo e passa a viver para Deus e para seus semelhantes. Este acolhimento é graça de Deus, é dom, é gratuito.

O novo relacionamento com Deus através de uma fé viva acarreta assim um novo relacionamento da pessoa com seus semelhantes, que não deixa de

\footnotetext{
${ }^{25}$ W. PANNENBERG, Reformation, p. 179-181.

${ }^{26}$ W. PANNENBERG, Christianity and the West. Ambiguous Past, Uncertain Future, em: Id., Kirche und Ökumene, p. 58s.
} 
ter repercussão na sociedade. O mundo da cultura, da família, da organização social, da vida profissional, da política, da economia não se situa fora do âmbito do Reino de Deus. Este tende realmente a construir uma nova humanidade caracterizada pela justiça, pela paz, pela partilha, pelo amor fraterno, realizando assim a soberania de Deus neste mundo ${ }^{27}$. Entretanto o advento do Reino não se dá tranquilamente e sem conflitos como nos comprova a história e o destino de Jesus Cristo. Pois a missão cristã é realizada num mundo já marcado pelo pecado e pelo egoísmo que reage quando se vê questionado pela mensagem evangélica. A quênose e a glorificação, a morte e a ressurreição, são componentes constitutivos da salvação cristã, do mistério pascal, da realização do Reino de Deus.

A compreensão adequada da noção do Reino de Deus levou o Conselho Mundial das Igrejas a incentivar a participação dos cristãos na luta por uma sociedade humana que diminua as desigualdades sociais, os sofrimentos dos mais pobres, a idolatria do mercado, a sustentabilidade do planeta, que teve início em Vancouver (1983) e deu alento ao movimento "Justiça, Paz e Integridade da Criação". No Brasil a preocupação pela situação das maiorias empobrecidas se concretizou pelos pronunciamentos sociais do CONIC, pelas teologias da libertação e pelos empenhos sociopolíticos por parte de membros das várias Igrejas cristãs no país. Tais atividades são profundamente cristãs porque Jesus não apenas proclamou a mensagem do Reino, mas também através de suas ações diminuiu os sofrimentos físicos ou morais daqueles que encontrava. Sem diminuir a importância da verdade no cristianismo sua dimensão ética ganha força crescente em nossos dias ${ }^{28}$.

A grande missão de um cristianismo unido em nossos dias é levar a mensagem cristã a uma sociedade secularizada. Uma sociedade cujos membros procuram viver apenas para satisfação de suas necessidades, de seus desejos, de seus sonhos de consumo. Uma sociedade cujos membros não mais perguntam pelo sentido da realidade, contentando-se com o que vêem, fechando-se ao Transcendente e dispensando qualquer referência a Deus. Deste modo os símbolos cristãos (Palavra de Deus, celebrações cúlticas, linguagem cristã) que tanto motivavam nossos antepassados pouco dizem para nossos contemporâneos, exigindo das Igrejas esforço inédito para se fazerem entender pelo mundo situado para além de seus fiéis. É importante que esta sociedade caia

\footnotetext{
${ }^{27}$ Ver G. LOHFINK, Deus precisa da Igreja? Teologia do Povo de Deus, S. Paulo, Loyola, 2008.

${ }^{28}$ J. RATZINGER, ob. cit. P. 246: "Le thème prioritaire du dialogue oecuménique devrait être la recherche de ce que le commandement de l'amour signifie concrètement en ce moment précis".
} 
na conta que o cristianismo humaniza o convívio social, melhora as condições de vida, aumenta a paz e diminui a violência, numa palavra, contribui para a felicidade do ser humano. Afirmamos isto sem desconhecer as tragédias, violências e sofrimentos ocasionados pelo cristianismo no passado, que devem ser corrigidos por nosso testemunho no presente ${ }^{29}$.

Agradeço de coração a atenção e a paciência com que vocês ouviram este cristão como vocês, para quem Jesus Cristo é o sentido último e o fundamento de toda a realidade $(\mathrm{Cl} 1,15-17)$ e no qual procuro investir esta vida passageira que Deus me concedeu na esperança de com Ele viver a felicidade eterna.

\author{
Mario de França Miranda \\ Doutor em Teologia Sistemática pela \\ Pontifícia Universidade Gregoriana - Roma \\ Professor de Teologia na PUC-Rio \\ E-mail: mfranca@puc-rio.br
}

Artigo Recebido em 23/02/2012

Artigo Aprovado em 26/04/2012

${ }^{29}$ Como afirmava já John Wesley: "If we cannot as yet think alike in all things, at least we may love alike. Herein we cannot possibly do amiss", M. HURLEY (ed), ob. cit., p. 56. 